\title{
Starševski stres in kakovost življenja družine otroka z obporodno hipoksijo, zdravljeno s hipotermijo
}

Povzetek: Preučevali smo kakovost življenja ter količino starševskega stresa pri družinah otrok s hipoksično ishemično encefalopatijo (HIE), zdravljeno s terapevtsko hipotermijo (TH). Starši 19 otrok (10 otrok z blago, 6 z zmerno in 3 s hudo HIE), starih od 6;0 do 9;4 let, so izpolnili vprašalnika PedsQL-FIM in PSI-III. Kot merilo razvojnega izida smo otrokom izmerili količnik inteligentnosti (IQ) z instrumentoma WISC-III ${ }^{S I}$ oziroma WPPSI-III ${ }^{S I}$. Kakovost življenja družin je bila v povprečju višja, starševski stres pa v območju povprečja glede na splošno populacijo. Družine so se v večini prilagodile dejavnikom tveganja za porušeno delovanje družine, ki jih prinaša otrokova bolezen, kar je skladno s teorijo o pozitivni prilagoditvi (dvojni ABC-X model). Tako kot v predhodnih raziskavah, ki so vključevale družine otrok s HIE in z nekaterimi drugimi kroničnimi boleznimi, smo v družinah otrok s podpovprečnim IQ ugotovili slabšo kakovost življenja družine in povišan starševski stres na nekaterih (ne pa vseh) področjih v primerjavi z družinami otrok s povprečnim ali nadpovprečnim IQ. Otrok s HIE, zdravljenih s TH, ne moremo obravnavati kot homogeno skupino, saj so razvojni izidi otrok različni, prav tako so specifične tudi značilnosti in potrebe otrok in njihovih družin. Starši so pogosto izpostavljali negotovost in strah, ki so ju doživljali po rojstvu otroka - ob diagnozi in akutnem zdravljenju otroka, zato se je pri raziskovanju delovanja družine smiselno usmeriti na zgodnje obdobje. Zdravstveni delavci morajo starše usmerjati k virom pomoči v lokalnem okolju, prav tako pa k tistim na državni ravni. Za starše sta pomembna pridobivanje informacij o naravi otrokovih težav in možnih oblikah pomoči, pa tudi strokovna terapevtska pomoč, kadar je to potrebno. Za nudenje optimalne podpore družinam kronično bolnih otrok je bistvena podpora zdravstvene in socialne politike.

Ključne besede: obporodna hipoksija, terapevtska hipotermija, razvojni izidi, kakovost življenja družine, starševski stres

\section{Parental stress and quality of life in families with children suffering from neonatal hypoxia treated with therapeutic hypothermia}

\author{
Manja Rančigaj Gajšek* and Metka Derganc \\ Department of Paediatric Surgery and Intensive Care, Division of Surgery, University Medical Centre Ljubljana, Slovenia
}

\begin{abstract}
We assessed the quality of life and the amount of parental stress in families with children treated with therapeutic hypothermia (TH) after hypoxic ischemic encephalopathy (HIE). Our sample included 19 children (10 with mild HIE, 6 with moderate HIE, and 3 children with severe HIE) and their parents. The children were 6 to 9 years old. Parents completed two questionnaires (PedsQL-FIM and PSI-III). As a developmental outcome indicator we measured the children's intelligence with WISC-III ${ }^{\mathrm{SI}}$ and WPPSI-III ${ }^{\text {SI }}$. The quality of life in participating families was better and parental stress did not differ significantly from normative values. Families have adapted to the risk factors for lower quality of life caused by the child's illness, which is consistent with the theory of positive adaptation (the dual ABC-X model). Poor quality of family life and increased parental stress in some (but not all) areas were found in families with children of an under average IQ in comparison with families with children of an average or above average IQ. This finding is consistent with previous studies involving families of children with HIE and some other chronic diseases. Developmental outcomes of children with HIE treated with TH are different with specific characteristics and needs of children and their families. Further investigation should be focused on the early period, as parents often expressed uncertainty and fear experienced after a diagnosis and acute treatment of the child. Health care professionals need to inform parents about sources of help in the local environment, as well as those available at the national level. It is important for parents to obtain information and education, as well as receive professional therapeutic help when necessary. In order to provide optimum support to families of chronically ill children, adequate health and social policy is essential.
\end{abstract}

Keywords: neonatal hypoxia, therapeutic hypothermia, developmental outcomes, family quality of life, parental stress

\footnotetext{
*Naslov/Address: Manja Rančigaj Gajšek, Klinični oddelek za otroško kirurgijo in intenzivno terapijo, Kirurška klinika, Univerzitetni klinični center Ljubljana, Bohoričeva ulica 20,1000 Ljubljana, e-mail: manja.rancigaj@kclj.si
}

Članek je licenciran pod pogoji Creative Commons Attribution 4.0 International licence. (CC-BY licenca). The article is licensed under a Creative Commons Attribution 4.0 International License (CC-BY license). 
Obporodni rizični dejavniki in potreba po intenzivnem zdravljenju novorojenčka, prav tako pa kasnejše življenje z otrokom z razvojnimi težavami, lahko pomembno vplivajo na izkušnjo starševstva ter delovanje družine. Terapevtska hipotermija (TH) je odprla novo poglavje v obravnavi otrok z obporodno hipoksijo, pri tem pa je za zdaj malo podatkov o dolgotrajnem sledenju razvoju ter kakovosti življenja teh otrok in njihovih družin. Za dolgoročni izid zdravja otroka ostajata ključnega pomena tudi odpornost in sodelovanje družine (Lemmon, Donohue, Parkinson, Northington in Boss, 2016). Starši oziroma skrbniki kronično bolnih otrok namenjajo več časa oskrbi otroka, doživljajo povišan stres, družinsko breme $\mathrm{v}$ teh družinah je večje, potrebujejo več socialne opore. Starši otrok, ki potrebujejo več zdravstvene oskrbe, imajo bolj negativne predstave o otrokovem zdravju. Razumevanje učinka otrokove kronične bolezni na starše in družino je pomembno za zagotavljanje ustrezne podpore družinam (Panepinto, Hoffmann in Pajewski, 2009).

\section{Obporodna hipoksija in terapevtska hipotermija}

Hipoksično ishemična encefalopatija (HIE) je poškodba možganov, ki se razvije $\mathrm{v}$ pozni nosečnosti ali ob porodu zaradi pomanjkanja kisika v krvi (in posledično tudi v tkivih ploda ali novorojenčka) in spremembe cirkulacije, vključno $\mathrm{S}$ cirkulacijo v osrednjem živčevju (Bregant, Neubauer in Derganc, 2012). Incidenca hude HIE v splošni populaciji je 1-4 na 1000 rojstev. HIE, ki nastane v perinatalnem obdobju, je najpogosteje prepoznan vzrok hudih, dolgoročnih nevroloških okvar pri otrocih (Volpe, 1995). Med novorojenčki z nevrološko oškodovanostjo jih 20-50 \% umre v obdobju novorojenčka, 25-60 \% pa jih ima stalne nevrološke težave, ki vključujejo cerebralno paralizo, krče, razvojni zaostanek in učne težave (Inder in Volpe, 2000).

S TH zmanjšujemo tveganje za možgansko poškodbo po HIE (Yager, Armstrong, Jaharus, Saucier in Wirrell, 2004). Trenutno obstajata dva pristopa: ohlajanje glave s posebej oblikovano kapo (CoolCap) s spremljajočo blago hipotermijo celotnega telesa (rektalna temperatura $34-35^{\circ} \mathrm{C}$ ) ter ohlajanje celega telesa s hladilno odejo z zmerno hipotermijo celotnega telesa (rektalna temperatura $33-34{ }^{\circ} \mathrm{C}$ ). TH se uvede $\mathrm{v}$ prvih šestih urah po hipoksično ishemičnem dogodku in se vzdržuje nadaljnjih 72 ur. Ogrevanje bolnika je postopno in počasno s pomočjo ogrevalnih odej (Radić, Grosek, Osredkar in Derganc, 2007). Hipotermija naj bi delovala varovalno s pomočjo zaviranja različnih procesov, ki lahko vodijo celo v smrt živčnih celic (Shankaran, 2012).

Šest velikih randomiziranih študij, ki so zajele več kot 1500 novorojenčkov s HIE med letoma 2005 in 2010, je potrdilo ugoden vpliv blage TH na kasnejši psihofizični razvoj. Po tem je TH postala priporočen način zdravljenja pri novorojenčkih s HIE v smernicah za reanimacijo novorojenčka in otroka European Resuscitation Council (Biarent idr., 2010). TH statistično značilno in klinično pomembno zmanjšuje kombiniran izid mortalitete in nevrorazvojnih motenj do 18. meseca starosti malčkov (Jacobs idr., 2013). Po uvedbi TH kot izbrane metode zdravljenja umre 25-30\% otrok, 45$50 \%$ otrok pa ima nevrološke okvare (Bonifacio, deVries in Groenendaal, 2015).
V Sloveniji s TH zdravimo novorojenčke od julija 2006 $\mathrm{V}$ enoti za intenzivno terapijo (EIT) Kliničnega oddelka za otroško kirurgijo in intenzivno terapijo (KO OKIT) v Univerzitetnem kliničnem centru (UKC) v Ljubljani. Do leta 2018 smo jih zdravili 79. M. Derganc s sodelavci (2015) v analizi navaja, da je $10 \%$ otrok umrlo, $10 \%$ preživelih je imelo hud razvojni zaostanek, $25 \%$ zmerne in $65 \%$ blage nevrološke motnje.

\section{Družina otroka z obporodnimi rizičnimi dejavniki in razvojnimi težavami}

Izkušnje staršev prezgodaj rojenih ali kritično bolnih novorojenčkov, ki se zdravijo v EIT, so povezane s stresom, strahom, skrbmi in občutki krivde. Mame zaradi ločenosti od otroka, ko se ta zdravi v EIT, pogosteje občutijo ambivalentnost in odtujenost $\mathrm{v}$ odnosu do novorojenčka in ta lahko vztraja tudi več let (Heringhaus, Blom in Wigert, 2013).

Prilagajanje otrokovi kronični bolezni lahko privede do žrtvovanja drugih razvojnih potreb družine in posameznikov znotraj nje (Cohen, 1999). Subjektivna kakovost življenja skrbnikov otrok z ovirami je pod povprečjem normalnega v zahodni populaciji (Werner in Shulman, 2013). Starši doživljajo strah in zaskrbljenost glede prihodnosti svojih otrok z ovirami. Skrb za otroka z ovirami vpliva na fizično in socialno blagostanje, zmožnost dela, svobodo in neodvisnost staršev, družinsko blagostanje, zakonske odnose in finančno stabilnost (Nimbalkar, Raithatha, Shah in Panchal, 2014). Vse omenjeno lahko ima potencialni povratni vpliv na zdravje in blagostanje bolnega oziroma oviranega otroka (Reichman, Corman in Noonan, 2008).

Starši otrok z razvojnimi težavami doživljajo večji stres kot starši zdravih otrok (Hastings, 2002; Scorgie idr., 1998, citirano v: Jones in Passey, 2004), pri čemer starševski stres v obdobju srednjega otroštva narašča (Abidin, 1995). Ob razvojnih mejnikih, kot je na primer vstop v šolo, se lahko težave, povezane $z$ otrokovimi primanjkljaji, povečajo (Keller in Sterling Honig, 2004). Učinki stresa se lahko pri starših izkazujejo kot izolacija, depresivnost in konfliktni odnosi. Stres, ki ga doživlja družina, je večji, kadar člani doživljajo negativne odzive družbe, kadar je potrebna dolgotrajna fizična oskrba otroka, pa tudi zaradi neprepoznanega žalovanja ob neuresničenih pričakovanjih, povezanih z otrokom. Poleg tega obstaja pogosto veliko finančno breme in odgovornost ter stalna skrb glede otrokove prihodnosti. Otroci z razvojnimi težavami pogosteje izkazujejo problematično vedenje, ki vztraja skozi čas (Totsika in Hastings, 2009, citirano v: Woodman, 2014), vedenjske težave in otrokov temperament pa sta močno povezana s starševskim stresom (Kazak in Marvin, 1984; Minnes, 1988). Hipoteza socialnih vlog predpostavlja, da so ženske bolj izpostavljene napetostim, povezanih s skrbjo za otroka in gospodinjstvo (Deater-Deckard in Scarr, 1996). Hipoteza o enakostih med spoloma na drugi strani (Hyde, 2005) pa poudarja podobnosti $\mathrm{v}$ psihološkem blagostanju med spoloma.

Stopnja prilagajanja družine je rezultat medsebojnega delovanja stresnega dogodka, družinskih virov, dojemanja situacije s strani staršev ter njihovih strategij za spoprijemanje. Družinska odpornost so značilnosti, dimenzije in lastnosti, ki pomagajo družini ostati odporna in prilagodljiva ob 
spremembah in kriznih situacijah (McCubbin in McCubbin, 1988). Nekatere značilnosti ali osebnostne lastnosti otroka s posebnimi potrebami lahko povzročijo stres v družini, medtem ko lahko imajo druge značilnosti nestresne učinke. V tem smislu se lahko otroci s posebnimi potrebami primerjajo z zdravimi otroki (Summers, Behr in Turnbull, 1988).

Izkušnja življenja z otrokom z razvojnimi težavami lahko vpliva na delovanje družine tudi v pozitivnem smislu, ko se poveča notranja moč družine, njena odpornost, povezanost ter povezava s skupnostjo (Lindo, Kliemann, Combes in Frank, 2016).

Pričujoča raziskava je prva v Sloveniji, ki je ugotavljala kakovost življenja družine ter starševski stres v družinah otrok, ki so bili kot novorojenčki zdravljeni s TH zaradi HIE, zdaj pa so v obdobju začetka šolanja. Za ugotavljanje kakovosti življenja v obdobju všolanja smo se odločili, ker je to čas, ko lahko ob povečanih zahtevah okolja (vstop v šolo) zaznamo pri otrocih subtilne, prej celo neprepoznane kognitivne in motorične nevrološke posebnosti (Marlow, Rose, Rands in Draper, 2005). Ker je KO OKIT v UKC Ljubljana osrednja ustanova, kjer se zdravi večina kritično bolnih novorojenčkov, je vzorec $\mathrm{v}$ naši raziskavi reprezentativen za celotno slovensko populacijo $\mathrm{v}$ času izvedbe raziskave. Analiza raziskav kakovosti življenja, povezane z zdravjem, je lahko v pomoč pri oblikovanju smernic in intervencij za izboljševanje stanja ter preprečevanje resnejših posledic (Centers for Disease Control and Prevention, 2016).

Dosedanje raziskave večinoma ugotavljajo negativne učinke otrokovih razvojnih težav in kroničnih bolezni na starševstvo in delovanje družine. Zato smo v družinah otrok v našem vzorcu pričakovali slabšo kakovost življenja družine ter povišan starševski stres v primerjavi z družinami z zdravimi otroki. Predvidevali smo več težav pri družinah otrok s hujšimi razvojnimi težavami kot pri družinah otrok $\mathrm{z}$ boljšimi razvojnimi izidi.

\section{Metoda}

\section{Udeleženci}

$\mathrm{V}$ raziskavo je bilo vključenih 24 otrok (12 deklic in 12 dečkov), ki so bili v času od julija 2006 do aprila 2010 na KO OKIT, UKC Ljubljana, zdravljeni s TH po HIE. S starši dveh otrok nismo uspeli navezati stika zaradi pomanjkanja kontaktnih podatkov. Na vabilo za sodelovanje so se odzvali starši 20 od 21 otrok. Starši enega otroka niso dostavili vprašalnikov, ki smo jim jih poslali po pošti. Na koncu smo podatke pridobili od staršev 19 otrok (79 \%), od tega 19 mam in 18 očetov. Iz zdravstvene dokumentacije smo pridobili podatek, da je imelo 10 otrok ob rojstvu opredeljeno blago do zmerno HIE, šest zmerno in trije otroci hudo HIE. V času psihološkega pregleda in izpolnjevanja vprašalnikov so bili otroci stari od 6;0 do 9;4 let, povprečna kronološka starost je bila 87,5 mesecev.

\section{Pripomočki}

Wechslerjeva lestvica inteligentnosti za predšolske otroke, 3. izdaja. WPPSI-III ${ }^{\mathrm{SI}}$ (Wechsler, Gosar, Boben in Kovačič 2013) je razvojno-psihološki pripomoček, namenjen ocenjevanju intelektualne sposobnosti otrok, starih od 2;6 do $7 ; 3$ leta. Lestvica vključuje Besedni, Nebesedni in Celotni količnik inteligentnosti (IQ) . Cronbachovi alfa koeficienti $(\alpha)$ notranje skladnosti (slovenski vzorec, $N=786$ ) so za Besedni IQ pri različnih starostih od 0,88 do 0,93 , za Nebesedni IQ 0,75 do 0,94 , za Celotni IQ 0,88 do 0,96, Norme predstavljajo IQ točke in percentilni rangi.

Wechslerjeva lestvica inteligentnosti za otroke, 3. izdaja. WISC-III ${ }^{\mathrm{SI}}$ (Wechsler, Boben, Bucik in Kovačič 2001) je namenjena individualnemu ugotavljanju inteligentnosti otrok, starih od 6;6 do 16;6 leta. Dobimo dosežek na celotni lestvici inteligentnosti ter na lestvici besedne in nebesedne inteligentnosti. $\alpha$ koeficienti so pri različnih starostih (slovenski vzorec $N=1080$ ) za Besedni IQ 0,90 do 0,94, Nebesedni IQ 0,88 do 0,91, Celotni IQ 0,88 do 0,92. Norme so $\mathrm{v}$ obliki IQ točk in percentilnih rangov predstavljene ločeno po starosti.

Vprašalnik o vplivu bolezni otroka na kakovost življenja staršev. Vprašalnik Pediatric Quality of Life Inventory - Family Impact Module (Parent report) (PedsQLFIM) - PedsQL 3.0 (Varni, Sherman, Burwinkle, Dickinson in Dixon, 2004), osnovan na modelu PedsQL ${ }^{\mathrm{TM}}$ (Varni, Seid in Rode, 1999) meri učinek otrokove bolezni ali oviranosti na kakovost življenja staršev in družine. Udeleženci ocenjujejo stopnjo težav $\mathrm{v}$ zadnjem mesecu na šestih podlestvicah: telesno delovanje (utrujenost, glavoboli, slabotnost in slabost), čustveno delovanje (tesnobnost, žalost, jeza, frustriranost, občutki nemoči in brezupa), socialno delovanje (občutki izoliranosti, pomanjkanje podpore drugih ter časa ali energije za družbene dejavnosti), kognitivno delovanje (vzdrževanje pozornosti, zmožnost pomnjenja ter hitrost mišljenja), komunikacija (težave v komunikaciji z ljudmi, ki ne razumejo družinskih okoliščin, pri pogovorih o otrokovem zdravstvenem stanju ter težave pri pogovorih z zdravstvenim osebjem) in zaskrbljenost (predvsem v zvezi z zdravljenjem otroka in s stranskimi učinki zdravljenja, glede odzivov drugih na zdravstveno stanje otroka, vpliva bolezni na ostale člane v družini ter otrokove prihodnosti). Na področju delovanja družine udeleženci ocenjujejo stopnjo težav na dveh podlestvicah: dnevne aktivnosti (težave na področju dnevnih aktivnosti, ki zahtevajo več časa in energije ter pomanjkanje časa in energije za dokončanje domačih hišnih opravil) in družinski odnosi (težave $\mathrm{v}$ družinskih odnosih, predvsem zaradi pomanjkljive komunikacije, medsebojnih konfliktov, stresa ter pomanjkanja skupnega odločanja ter iskanja rešitev v družini). Tri lestvice ponujajo dodatne ocene kakovosti življenja družine: Telesno in psihosocialno zdravje (seštevek dosežkov na podlestvicah: telesno, čustveno, socialno in kognitivno delovanje), Kakovost delovanja družine (seštevek dosežkov na dimenzijah: dnevne dejavnosti in družinski 
odnosi) ter Kakovost življenja staršev (seštevek dosežkov na vseh dimenzijah). Notranja skladnost $(N=23)$ skupnega dosežka je 0,97, Lestvice z zdravjem povezane kakovosti življenja staršev 0,96, Lestvice kakovosti delovanja družine $0,90, \alpha$ za posamezne lestvice pa so znašale 0,82 do 0,97 (Varni idr., 2004). Slovenski prevod vprašalnika je z dovoljenjem za akademske namene dostopen na spletni strani The PedsQL ${ }^{\mathrm{TM}}$ (Varni, 2017). Slovenski prevod vprašalnika smo povzeli po raziskavi I. Kreft (2011).

Vprašalnik za ugotavljanje stresa pri starših, 3. izdaja. Vprašalnik Parenting Stress Index, Third edition - PSI-III (Abidin, 1995) je samoocenjevalni vprašalnik za starše otrok, starih od 1 meseca do 12 let, ki ocenjuje stres na treh področjih odnosa starš-otrok: stres zaradi značilnosti otroka, stres zaradi značilnosti starša in situacijski stres. Med značilnostmi otroka se posamezne postavke združujejo v šest podlestvic: hiperaktivnost (prekomerna aktivnost, nemir, odkrenljivost, znižana pozornost, neposlušnost, nezmožnost dokončanja začete aktivnosti, težave $\mathrm{z}$ osredotočanjem na domačo nalogo), prilagodljivost (otrok se ne zmore prilagoditi na spremembe v fizičnem ali socialnem okolju; perseveracija in nezmožnost preklapljanja med dejavnostmi, pretirana reakcija na spremembe $\mathrm{v}$ senzorni stimulaciji in v običajnih rutinah, izogibanje tujcem, težko se pomiri, ko je razburjen), krepitev starševske vloge (interakcije med otrokom in staršem vzbujajo pri staršu negativne občutke o sebi, starš se morda čuti zavrnjenega s strani otroka), zahtevnost (starši doživljajo, da jim otrok postavlja mnoge zahteve, kar se kaže na primer z jokom, oklepanjem starša, pogostimi prošnjami po pomoči ali s pogostimi blago problematičnimi vedenji), razpoloženje (nezadovoljen, depresivno razpoložen, jokav otrok) in sprejemljivost (otrok po svojih fizičnih, intelektualnih in čustvenih značilnostih ni zadovoljil starševskih pričakovanj). Med značilnostmi starša so ocene združene $\mathrm{v}$ sedem podlestvic: kompetence (starš se ne počuti kompetentno v svoji starševski vlogi), izolacija (starš ima občutek, da nima dovolj stika s prijatelji, sorodniki in $\mathrm{z}$ drugimi viri podpore), navezanost (starš ne občuti čustvene bližine do otroka ali pa starš napačno ocenjuje in razume otrokova čustva in potrebe), zdravje (starš občuti telesne težave, ki so lahko posledica starševstva ali kakšnega drugega vira stresa $\mathrm{v}$ odnosu starš-otrok), omejitev vloge (starš občuti, da ga starševska vloga ovira pri ohranjanju lastne identitete), depresivnost (starš občuti, da nima dovolj fizične in psihične energije za starševsko vlogo, kar se pogosto kaže v umiku in splošni nezmožnosti za ravnanje $\mathrm{z}$ asertivnostjo in avtoriteto) ter partner (starš ocenjuje, da nima dovolj čustvene in aktivne podpore v drugem staršu pri vzgoji otroka). Skupni stres je združitev ocene stresa na vseh podlestvicah. Dosežke naših udeležencev smo primerjali z vzorcem avtorjev preizkusa, ki vsebuje 2633 mam, vzorčenih naključno. Avtorji so zbrali tudi normativne podatke za očete $(N=200)$, s katerimi smo dodatno primerjali dosežke očetov v našem vzorcu, saj avtorji ugotavljajo, da imajo očetje v splošnem nižje dosežke na vprašalniku v primerjavi z mamami. Koeficient $\alpha$ je na vseh lestvicah višji od 0,70 (vrednost skupnega $\alpha$ je znašala 0,95 ) (Abidin, 1995). Slovenski prevod vprašalnika smo povzeli po raziskavi I. Kreft (2011).

\section{Postopek}

Staršem otrok, ki so bili na KO OKIT po HIE, zdravljeni s TH, smo poslali pisno obvestilo o dolgoročnem spremljanju otrok po HIE in povabilo k sodelovanju. Starši nekaterih otrok so se sami odzvali, druge pa smo ponovno poskušali pridobiti preko pošte ali telefona. Če so privolili v sodelovanje, smo se dogovorili za termine psiholoških pregledov, ki smo jih izvajali na KO OKIT. Pridobili smo informirano pisno soglasje staršev za sodelovanje. Pridobili smo soglasje Komisije Republike Slovenije za medicinsko etiko k izvedbi raziskave.

S pripomočkoma WISC-III ${ }^{\mathrm{SI}}$ in WPPSI-III ${ }^{\mathrm{SI}}$ smo ocenjevali intelektualne sposobnosti otrok. Glede na dosežen IQ smo jih razdelili v tri skupine. Tisti, ki so imeli podpovprečni dosežek (nižji ali enak 89), so bili uvrščeni v skupino 1, otroci s povprečnim IQ (med 90 in 109) v skupino 2, tisti z nadpovprečnim IQ (višjim ali enakim 110) pa v skupino 3. Otroke, ki se psihološkega pregleda niso udeležili in so imeli opredeljen hud nevrološki zaostanek, smo uvrstili v skupino 1. Starši otrok so v času pregleda otroka izpolnjevali vprašalnike. Staršem tistih otrok, ki v psihološkem pregledu zaradi morebitnih oviranosti ali drugi razlogov niso sodelovali, smo na dom poslali vprašalnike $\mathrm{z}$ navodili in sredstvi za povratno pošiljanje izpolnjenih vprašalnikov. Vsak vprašalnik sta ločeno izpolnjevala mama in oče.

Vprašalnike smo vrednotili $\mathrm{V}$ skladu $\mathrm{z}$ navodili $\mathrm{za}$ vrednotenje iz priročnikov. Vse zbrane podatke smo statistično obdelali s programskim paketom IBM SPSS Statistics 17.0. Izračunali smo opisne statistike in preverili normalnost porazdelitev podatkov na posameznih spremenljivkah. Za slednje smo izvedli Kolmogorov-Smirnov test, pregledali mere asimetrije in sproščenosti ter porazdelitve preverili $\mathrm{s}$ slikovnimi metodami (histogram in Q-Q test). Odstopanja od normalnosti so bila pri večini porazdelitev majhna do zmerna. Dosežke na vprašalnikih smo z enosmernim $t$-testom primerjali z normativnimi podatki avtorjev vprašalnikov, če so bili norme na voljo. S $t$-testom za odvisna vzorca smo preverili razlike med dosežki mam in očetov. $Z$ mero velikosti učinka Cohenov $d$ smo opredelili praktično pomembnost preučevanih učinkov. S Pearsonovim koeficientom korelacije smo preverili skladnost ocen mam in očetov. Preverili smo razlike $\mathrm{v}$ dosežkih med skupinami družin z otroki z različnimi razvojnimi izidi (skupine 1, 2 in 3). V tem primeru so bile ob še manjših vzorcih porazdelitve podatkov na posameznih spremenljivkah pomembno drugačne od normalnih. Za primerjavo med več skupinami smo zato uporabili KruskalWallisov test in pri izvedbi post-hoc primerjav z MannWhitneyevimi testi uporabili Bonferronijev popravek za več primerjav. Velikosti učinkov pri teh primerjavah smo opredelili s Pearsonovimi $r$ koeficientom. Po splošno sprejetih merilih za velikost učinka smo sledili sledečim mejnim vrednostim: majhen $(d=0,2 ; r=0,10)$, srednji $(d=0,5 ; r=0,30)$ in velik $(d=0,8 ; r=0,50)$. 


\section{Rezultati}

\section{Primerjava družin otroka s HIE (zdravljeno s TH) z normativnimi podatki}

Zanimalo nas je, ali se kakovost življenja družine ter količina starševskega stresa $\mathrm{v}$ družinah otrok $\mathrm{s}$ HIE $\mathrm{V}$ povprečju razlikujeta od stanja $\mathrm{v}$ družinah $\mathrm{z}$ zdravimi otroki. Povprečne dosežke staršev otrok iz našega vzorca na uporabljenih vprašalnikih smo primerjali z normativnimi podatki. Med seboj smo primerjali tudi povprečne dosežke mater in očetov, da bi ugotovili, ali se med njimi pojavljajo pomembne razlike. Prav tako smo preverili skladnost ocen mam in očetov s Pearsononovim koeficientom korelacije.

Med ocenami mam in očetov obstaja na večini merjenih lestvic vsaj zmerna korelacija, iz česar lahko sklepamo, da so ocene razmeroma skladne. Nizke ali zanemarljive korelacije med ocenami so se pokazale na vprašalniku PedsQL-FIM na lestvicah Čustveno delovanje, Socialno delovanje in Kognitivno delovanje $(r=0,33$ do 0,38$)$ ter na vprašalniku PSI-III na lestvicah Kompetentnost $(r=-0,12)$, Zdravje $(r=0,14)$ ter Omejitev vloge $(r=0,27)$.

Iz tabele 1 je razvidno, da so mame in očetje poročali o visoki kakovosti življenja na vseh področjih. Očetje so poročali o statistično pomembno višji kakovosti življenja kot mame na področju družinskih odnosov s srednjo velikostjo učinka $(d>0,5)$. Glede na srednjo velikost učinka so se kot nezanemarljive izkazale tudi višje ocene očetov v primerjavi z mamami na področjih telesnega $(d=0,56)$, čustvenega $(d$ $=0,60)$ in kognitivnega delovanja $(d=0,56)$ ter pri skupnem rezultatu kakovosti življenja staršev $(d=0,59)$.

Tabela 2 prikazuje primerjavo ocenjenega starševskega stresaznormativnimipodatki(Abidin, 1995).MedZnačilnostmi otroka so bile ocene očetov statistično pomembno nižje s srednjo velikostjo učinka na podlestvici Krepitev starševske vloge. Med Značilnostmi starša so bile povprečne ocene mam statistično pomembno nižje od normativnega povprečja $s$ srednjo velikostjo učinka na podlestvici Kompetence, ocene očetov pa statistično pomembno nižje od normativnega povprečja na podlestvicah Kompetence, Zdravje, Omejitev vloge in Partner z veliko velikostjo učinka ter Skupni stres in Življenjski stres s srednjo velikostjo učinka. Dosežke očetov smo posebej primerjali tudi z normami, pridobljenimi na sto moških udeležencih (Abidin, 1995). Dosežki očetov našega vzorca so bili med Značilnostmi otroka statistično pomembno nižji na podlestvicah Krepitev starševske vloge $(t(17)=-5,14$, $p<0,01, d=1,32)$ in Razpoloženje $(t(17)=-3,28, p<0,01$, $d=0,84)$, med Značilnostmi starša pa na področjih Zdravje $(t(17)=-3,83, p<0,01, d=0,98)$ in Partner $(t(17)=-3,38$, $p<0,01, d=0,87)$ ter na lestvici Skupni stres $(t(17)=-2,12$, $p=0,05, d=0,54)$.

Mame so poročale o statistično pomembno višjem starševskem stresu kot očetje z veliko velikostjo učinka na področju Značilnosti otroka na podlestvicah Krepitev starševske vloge in Sprejemljivost. Višje so bile še ocene mam na podlestvici Hiperaktivnost s srednjo velikostjo učinka. Na področju Značilnosti starša so bile ocene mam statistično pomembno višje od ocen očetov $\mathrm{z}$ veliko velikostjo učinka na podlestvici Depresivnost. Mame so imele statistično pomembno višje dosežke kot očetje na Lestvici obrambnega odgovarjanja.

\section{Kakovost življenja družine glede na razvojni izid otroka v obdobju všolanja}

Udeleženim otrokom smo izmerili količnik inteligentnosti (IQ) in jih na podlagi rezultata razdelili v tri skupine. Osem otrok je imelo izmerjen IQ pod povprečjem (89 ali manj), sedem otrok je imelo povprečni IQ (90 do 109), štirje otroci pa so imeli izmerjen IQ nad povprečjem (110 ali več).

$\mathrm{V}$ tabeli 3 so prikazani rezultati posameznih skupin na vprašalniku PedsQL-FIM ter statistično pomembne parne

Tabela 1. Opisne statistike in razlike med dosežki staršev na Vprašalniku o vplivu bolezni otroka na kakovost življenja staršev (PedsQL-FIM)

\begin{tabular}{|c|c|c|c|c|c|c|}
\hline \multirow[b]{2}{*}{ Dimenzije in poddimenzije } & \multicolumn{2}{|c|}{ mama $(N=19)$} & \multicolumn{2}{|c|}{ oče $(N=18)$} & \multicolumn{2}{|c|}{ razlika med staršema } \\
\hline & $M$ & $S D$ & $M$ & $S D$ & $t(17)$ & Cohenov $d$ \\
\hline \multicolumn{7}{|l|}{ Delovanje staršev } \\
\hline Telesno delovanje & 78,95 & 21,76 & 85,39 & 12,39 & $-1,67$ & 0,56 \\
\hline Čustveno delovanje & 78,68 & 23,26 & 88,61 & 12,34 & $-1,81$ & 0,60 \\
\hline Socialno delovanje & 73,16 & 29,79 & 81,39 & 26,96 & $-1,15$ & 0,38 \\
\hline Kognitivno delovanje & 77,89 & 19,74 & 85,83 & 17,43 & $-1,68$ & 0,56 \\
\hline Komunikacija & 85,32 & 21,74 & 85,89 & 22,46 & $-0,12$ & 0,04 \\
\hline Zaskrbljenost & 80,26 & 23,89 & 76,67 & 22,43 & 0,92 & 0,31 \\
\hline \multicolumn{7}{|l|}{ Delovanje družine } \\
\hline Dnevne aktivnosti & 73,89 & 29,93 & 74,28 & 31,74 & $-0,40$ & 0,13 \\
\hline Družinski odnosi & 79,05 & 24,40 & 88,33 & 16,27 & $-2,34^{*}$ & 0,78 \\
\hline \multicolumn{7}{|l|}{ Skupni dosežki } \\
\hline Skupni rezultat & 78,06 & 19,87 & 83,56 & 13,57 & $-1,47$ & 0,49 \\
\hline Kakovost delovanja družine & 77,89 & 24,50 & 82,83 & 18,52 & $-1,17$ & 0,39 \\
\hline Kakovost življenja staršev & 76,78 & 21,71 & 85,28 & 13,55 & $-1,76$ & 0,59 \\
\hline
\end{tabular}

Opomba. Minimalni surovi dosežek je 0, maksimalni pa 100 .

${ }^{*} p<0,05 ;{ }^{* *} p<0,01$. 
Tabela 2. Opisne statistike in primerjava dosežkov z normativnimi podatki ter razlike med dosežki staršev na Vprašalniku za ugotavljanje stresa pri starših (PSI-III)

\begin{tabular}{|c|c|c|c|c|c|c|c|c|c|c|c|c|}
\hline \multirow[b]{2}{*}{ Lestvice in podlestvice } & \multicolumn{5}{|c|}{ mama } & \multicolumn{5}{|c|}{ oče } & \multicolumn{2}{|c|}{$\begin{array}{c}\text { razlika med } \\
\text { staršema }\end{array}$} \\
\hline & $M$ & $S D$ & $t(18)$ & $d$ & $P$ & $M$ & $S D$ & $t(17)$ & $d$ & $P$ & $t(17)$ & $d$ \\
\hline Značilnosti otroka & 99,58 & 26,06 & $-0,02$ & 0,00 & 55 & 91,11 & 21,54 & $-1,69$ & 0,40 & $30-35$ & $-2,62^{*}$ & 0,86 \\
\hline Hiperaktivnost & 24,95 & 6,33 & 0,17 & 0,04 & 60 & 23,56 & 5,87 & $-0,83$ & 0,20 & 55 & $-1,52$ & 0,50 \\
\hline Prilagodljivost & 24,53 & 10,92 & $-0,16$ & 0,04 & 55 & 22,33 & 8,10 & $-1,34$ & 0,32 & 35 & 0,95 & 0,31 \\
\hline $\begin{array}{l}\text { Krepitev starševske } \\
\text { vloge }\end{array}$ & 9,11 & 1,91 & $-0,67$ & 0,15 & 55 & 7,94 & 1,86 & $-3,32^{*}$ & 0,79 & 45 & $-3,12^{*}$ & 1,03 \\
\hline Zahtevnost & 17,58 & 5,62 & $-0,56$ & 0,13 & 55 & 17,44 & 5,57 & $-0,65$ & 0,15 & 45 & 0,35 & 0,12 \\
\hline Razpoloženje & 9,95 & 3,50 & 0,31 & 0,07 & 60 & 8,89 & 2,47 & $-1,39$ & 0,33 & 50 & $-1,40$ & 0,46 \\
\hline Sprejemljivost & 13,68 & 5,47 & 0,86 & 0,20 & 70 & 11,11 & 4,11 & $-1,54$ & 0,36 & 40 & $3,45^{*}$ & 1,13 \\
\hline Značilnosti starša & 114,84 & 28,05 & $-1,28$ & 0,29 & 40 & 104,56 & 20,44 & $-3,85^{*}$ & 0,91 & $20-25$ & $-1,56$ & 0,51 \\
\hline Kompetence & 25,32 & 5,74 & $-2,88^{*}$ & 0,66 & 30 & 23,67 & 5,02 & $-4,59^{*}$ & 1,09 & 25 & 0,70 & 0,23 \\
\hline Izolacija & 13,95 & 5,24 & 1,12 & 0,26 & 70 & 13,22 & 4,05 & 0,65 & 0,15 & 60 & $-0,55$ & 0,18 \\
\hline Navezanost & 12,11 & 2,62 & $-0,99$ & 0,23 & 50 & 11,22 & 3,28 & $-1,91$ & 0,45 & 35 & 1,21 & 0,40 \\
\hline Zdravje & 11,47 & 2,09 & $-0,24$ & 0,06 & 50 & 9,78 & 2,13 & $-3,83^{*}$ & 0,91 & 35 & $-1,50$ & 0,49 \\
\hline Omejitev vloge & 16,84 & 6,59 & $-1,36$ & 0,31 & 40 & 15,06 & 4,49 & $-3,63^{*}$ & 0,86 & 25 & 1,04 & 0,34 \\
\hline Depresivnost & 21,63 & 5,66 & 1,03 & 0,24 & 70 & 18,39 & 4,82 & $-1,68$ & 0,40 & 35 & $-2,52^{*}$ & 0,83 \\
\hline Partner & 13,53 & 5,83 & $-2,52^{*}$ & 0,58 & 35 & 13,22 & 4,62 & $-3,38^{*}$ & 0,80 & 25 & 0,38 & 0,12 \\
\hline Skupni stres & 214,42 & 51,98 & $-0,70$ & 0,16 & 40 & 195,67 & 38,63 & $-2,98^{*}$ & 0,70 & 25 & 2,08 & 0,68 \\
\hline Življenjski stres & 4,74 & 4,59 & $-2,91^{*}$ & 0,67 & 40 & 4,94 & 4,95 & $-2,45^{*}$ & 0,58 & 40 & 0,15 & 0,05 \\
\hline Obrambno odgovarjanje & 35,26 & 10,68 & & & & 30,56 & 7,01 & & & & $2,11^{*}$ & 0,69 \\
\hline
\end{tabular}

Opomba. Surovi podatki so pretvorjeni v percentilne range $(P) . d=$ Cohenov $d$.

${ }^{*} p<0,05$.

${ }^{a} \mathrm{Za}$ lestvico »Obrambno odgovarjanje« normativni podatki ne obstajajo.

Tabela 3. Primerjava dosežkov staršev na PedsQL-FIM med skupinami otrok z različnim izmerjenim IQ (IQ 89 in manj $=1$, $I Q 90$ do $109=2$, IQ 110 in več $=3$ )

\begin{tabular}{|c|c|c|c|c|c|c|c|c|c|c|c|}
\hline \multirow[b]{2}{*}{ Dimenzije in poddimenzije } & \multicolumn{3}{|c|}{ Skupina $1(N=8)$} & \multicolumn{3}{|c|}{ Skupina $2(N=7)$} & \multicolumn{3}{|c|}{ Skupina $3(N=4)$} & \multirow[b]{2}{*}{$\chi^{2}(2)$} & \multirow{2}{*}{$\begin{array}{l}\text { parne } \\
\text { razlike }^{\mathrm{a}}\end{array}$} \\
\hline & $M d n$ & Min & $\operatorname{Max}$ & $M d n$ & Min & $\operatorname{Max}$ & $M d n$ & Min & $\operatorname{Max}$ & & \\
\hline \multicolumn{12}{|l|}{ Delovanje staršev } \\
\hline Telesno delovanje & 80,00 & 55,00 & 100,00 & 90,00 & 47,00 & 100,00 & 86,00 & 77,00 & 100,00 & 2,42 & \\
\hline Čustveno delovanje & 80,67 & 52,00 & 100,00 & 90,00 & 60,00 & 100,00 & 88,50 & 65,00 & 97,00 & 2,73 & \\
\hline Socialno delovanje & 69,00 & 25,00 & 100,00 & 92,00 & 40,00 & 100,00 & 84,00 & 68,00 & 100,00 & 4,98 & \\
\hline Kognitivno delovanje & 81,75 & 60,00 & 100,00 & 87,00 & 55,00 & 100,00 & 80,00 & 52,00 & 95,00 & 1,02 & \\
\hline Komunikacija & 79,00 & 37,00 & 95,00 & 97,50 & 91,00 & 100,00 & 96,67 & 83,00 & 100,00 & $9,20^{*}$ & $1-2^{*}$ \\
\hline Zaskrbljenost & 60,00 & 40,00 & 95,00 & 95,00 & 70,00 & 100,00 & 94,25 & 77,00 & 100,00 & $9,29^{*}$ & $1-2^{*}$ \\
\hline \multicolumn{12}{|l|}{ Delovanje družine } \\
\hline Dnevne aktivnosti & 45,50 & 16,00 & 91,00 & 97,00 & 53,00 & 100,00 & 91,50 & 83,00 & 100,00 & $8,91^{*}$ & $1-2^{*}$ \\
\hline Družinski odnosi & 77,00 & 42,00 & 100,00 & 99,00 & 75,00 & 100,00 & 85,00 & 55,00 & 100,00 & 5,93 & \\
\hline \multicolumn{12}{|l|}{ Skupni dosežki } \\
\hline Skupni rezultat & 74,50 & 50,00 & 84,00 & 91,00 & 64,00 & 100,00 & 88,00 & 70,00 & 96,00 & $6,44^{*}$ & \\
\hline Kakovost delovanja družine & 64,50 & 38,00 & 91,00 & 91,00 & 66,00 & 100,00 & 87,00 & 65,00 & 100,00 & $8,54^{*}$ & $1-2^{*}$ \\
\hline Kakovost življenja staršev & 77,00 & 55,00 & 96,00 & 97,60 & 51,00 & 100,00 & 84,50 & 69,00 & 94,00 & 2,24 & \\
\hline
\end{tabular}

Opomba. Minimalni možni surovi dosežek je 0 , maksimalni pa 100.

${ }^{*} p<0,05$.

${ }^{a}$ Statistično značilne parne razlike; Mann-Whitney test in Bonferronijev popravek za več primerjav. 


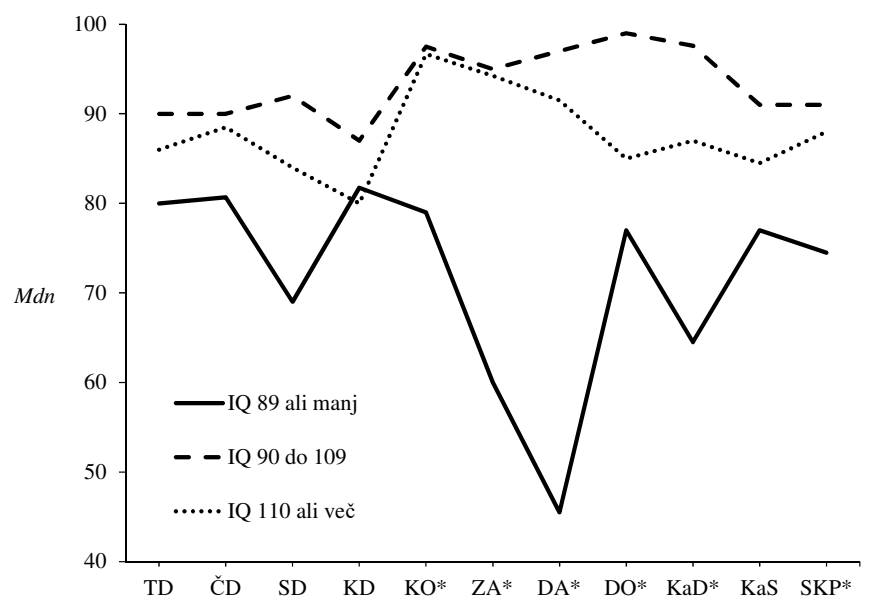

Slika 1. Mediane ocen staršev v skupinah otrok z različnimi izidi IQ na vprašalniku PedsQL-FIM. Poddimenzije, pri katerih so razlike med skupinami statistično pomembne, so označene z znakom *.(poddimenzije: TD = telesno delovanje, $\breve{C D}=$ čustveno delovanje, $\mathrm{SD}=$ socialno delovanje, $\mathrm{KD}=$ kognitivno delovanje, $\mathrm{KO}=$ komunikacija, $\mathrm{ZA}=$ zaskrbljenost, $\mathrm{DA}=$ dnevne aktivnosti, $\mathrm{DO}=$ družinski odnosi, $\mathrm{KaD}=$ kakovost delovanja družine, $\mathrm{KaS}=$ kakovost življenja staršev, SKP = skupni rezultat).

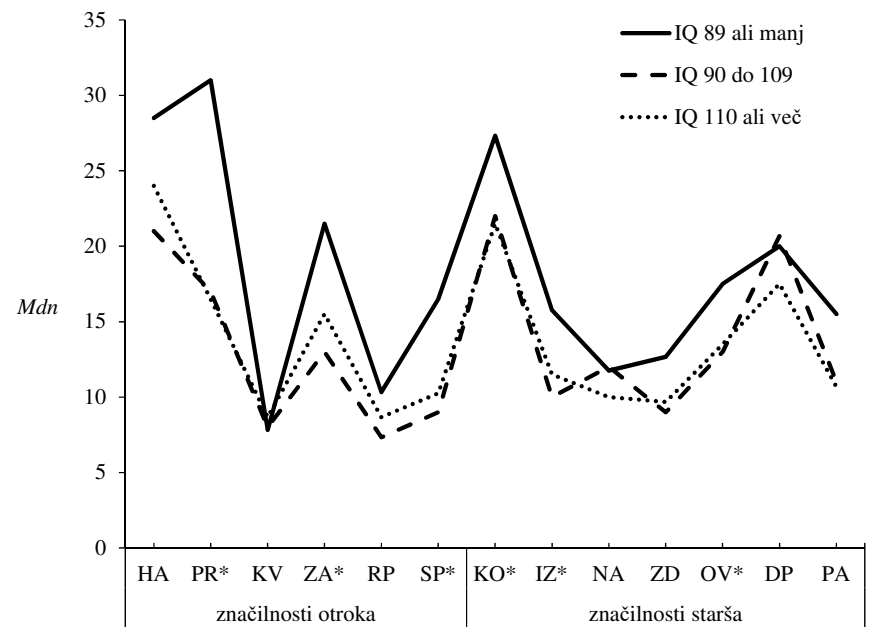

Slika 2. Mediane ocen staršev v skupinah otrok z različnimi izidi IQ na vprašalniku PSI-III. Podlestvice, na katerih so razlike med skupinami statistično pomembne, so označene z znakom * (podlestvice: HA = hiperaktivnost, $\mathrm{PR}=$ prilagodljivost, $\mathrm{KV}=$ krepitev starševske vloge, $\mathrm{ZA}$ = zahtevnost, $\mathrm{RP}=$ razpoloženje, $\mathrm{SP}=$ sprejemljivost, $\mathrm{KO}=$ kompetence, $\mathrm{IZ}=$ izolacija, $\mathrm{NA}=$ navezanost, $\mathrm{ZD}$ $=$ zdravje, $\mathrm{OV}=$ omejitev vloge, $\mathrm{DP}=$ depresivnost, $\mathrm{PA}=$ partner).

Tabela 4. Primerjava dosežkov staršev na PSI-III pri starših med skupinami otrok z različnim izmerjenim IQ (IQ 89 in manj $=1, I Q 90$ do $109=2, I Q 110$ in več $=3$ )

\begin{tabular}{|c|c|c|c|c|c|c|c|c|c|c|c|}
\hline \multirow[b]{2}{*}{ Lestvice in podlestvice } & \multicolumn{3}{|c|}{ Skupina $1(N=8)$} & \multicolumn{3}{|c|}{ Skupina $2(N=7)$} & \multicolumn{3}{|c|}{ Skupina $3(N=4)$} & \multirow[b]{2}{*}{$\chi^{2}(2)$} & \multirow{2}{*}{$\begin{array}{l}\text { parne } \\
\text { razlike }^{\mathrm{a}}\end{array}$} \\
\hline & $M d n$ & Min & $\operatorname{Max}$ & $M d n$ & Min & $\operatorname{Max}$ & $M d n$ & Min & $\operatorname{Max}$ & & \\
\hline Značilnosti otroka & 116,5 & 92,0 & 150,0 & 75,0 & 66,0 & 89,0 & 82,0 & 73,0 & 116,0 & $11,82^{*}$ & $1-2^{*}$ \\
\hline Hiperaktivnost & 28,5 & 17,0 & 34,0 & 21,0 & 15,0 & 26,0 & 24,0 & 19,0 & 30,0 & 2,53 & \\
\hline Prilagodljivost & 31,0 & 19,0 & 42,0 & 17,0 & 14,0 & 21,0 & 18,5 & 14,0 & 30,0 & $10,45^{*}$ & $1-2^{*}$ \\
\hline Krepitev starševske vloge & 7,8 & 7,0 & 10,0 & 8,0 & 6,0 & 11,0 & 8,7 & 8,0 & 11,0 & 1,28 & \\
\hline Zahtevnost & 21,5 & 16,0 & 30,0 & 13,0 & 11,0 & 14,0 & 15,5 & 12,0 & 17,0 & $13,30^{*}$ & $1-2^{*}$ \\
\hline Razpoloženje & 10,3 & 7,0 & 15,0 & 7,33 & 5,0 & 11,0 & 8,7 & 8,0 & 13,0 & 4,48 & \\
\hline Sprejemljivost & 16,5 & 11,0 & 21,0 & 9,0 & 7,0 & 10,0 & 10,3 & 8,0 & 17,0 & $10,93^{*}$ & $1-2^{*}$ \\
\hline Značilnosti starša & 121,5 & 105,0 & 156,0 & 103,0 & 81,0 & 116,0 & 90,0 & 78,0 & 130,0 & $8,60^{*}$ & $1-2^{*}$ \\
\hline Kompetence & 27,3 & 23,0 & 32,0 & 22,0 & 20,0 & 27,0 & 21,5 & 18,0 & 26,0 & $7,48^{*}$ & \\
\hline Izolacija & 15,8 & 14,0 & 21,0 & 10,0 & 8,0 & 15,0 & 11,5 & 7,0 & 15,0 & $10,39^{*}$ & $1-2^{*}$ \\
\hline Navezanost & 11,8 & 9,0 & 16,0 & 12,0 & 8,0 & 14,0 & 10,0 & 7,0 & 14,0 & 1,16 & \\
\hline Zdravje & 12,7 & 7,0 & 15,0 & 9,0 & 8,0 & 11,0 & 9,7 & 7,0 & 12,0 & 5,83 & \\
\hline Omejitev vloge & 17,5 & 15,0 & 26,0 & 13,0 & 11,0 & 18,0 & 13,5 & 9,0 & 19,0 & $6,49^{*}$ & $1-2^{*}$ \\
\hline Depresivnost & 20,0 & 16,0 & 29,0 & 20,67 & 13,0 & 24,0 & 17,5 & 11,0 & 22,0 & 1,71 & \\
\hline Partner & 15,5 & 11,0 & 25,0 & 11,0 & 8,0 & 14,0 & 10,7 & 8,0 & 20,0 & 4,94 & \\
\hline Skupni stres & 234,0 & 209,0 & 307,0 & 179,0 & 147,0 & 202,0 & 171,0 & 154,0 & 246,0 & $10,09^{*}$ & $1-2^{*}$ \\
\hline Življenjski stres & 3,3 & 0,0 & 5,0 & 4,67 & 0,0 & 16,0 & 5,5 & 3,0 & 11,0 & 1,90 & \\
\hline Obrambno odgovarjanje & 38,5 & 29,0 & 50,0 & 29,0 & 21,0 & 37,0 & 26,5 & 22,0 & 39,0 & $6,57^{*}$ & \\
\hline
\end{tabular}

${ }^{*} p<0,05$.

${ }^{a}$ Statistično značilne parne razlike; Mann-Whitney test in Bonferronijev popravek za več primerjav.

razlike med skupinami (npr. 1-2 pomeni, da sta se povprečji skupin 1 in 2 statistično pomembno razlikovali). Razlike, ki so se izkazale kot statistično pomembne, so prikazane na sliki 1. Pri vseh statistično pomembnih razlikah med skupinama 1 in 2 so velikosti učinka velike $(r>0,5)$.
V tabeli 4 so prikazani rezultati posameznih skupin na vprašalniku PSI-III ter pomembne razlike med skupinami. Starševski stres je bil na nekaterih podlestvicah različno izražen pri starših otrok z različnimi IQ (slika 2). Pri vseh statistično pomembnih razlikah med skupinama 1 in 2 so velikosti učinka velike $(r>0,5)$. 


\section{Razprava}

\section{Primerjava družin otroka s HIE (zdravljeno s TH) z normativnimi podatki}

$\mathrm{V}$ nasprotju s pričakovanji so rezultati $\mathrm{z}$ zdravjem povezane kakovosti življenja družin otrok s HIE višji kot v vzorcu iz splošne populacije (Medrano, Berlin in Davies, 2013), starševski stres pa nižji od normativnega, predvsem pri očetih. Večina staršev v našem vzorcu ima več kot enega otroka, iz česar lahko sklepamo, da imajo dovolj izkušenj, da se ne doživljajo kot nekompetentne. Povišane vrednosti stresa na področju lastne kompetentnosti namreč najpogosteje dosegajo starši, ki nimajo veliko znanja o razvoju otroka in tisti, ki nimajo veliko spretnosti pri ravnanju z otroki (Abidin, 1995). Zdravstveno stanje staršev očitno ni pomemben vir stresa, kar se ujema tudi z visoko oceno kakovosti življenja na področju telesnega delovanja pri mamah in še posebej pri očetih. Starši ne občutijo, da starševstvo omejuje njihovo svobodo ali jim onemogoča ohranjati lastno identiteto. Občutek nadzorovanosti in vodenosti z zahtevami in potrebami otroka je pogosto $\mathrm{v}$ najvišji meri prisoten pri mamah v prvem letu po rojstvu prvega otroka (Abidin, 1995), otroci v našem vzorcu pa so že starejši. Podpora moža igra pomembno vlogo $\mathrm{v}$ uravnavanju materinega starševskega stresa preko mehanizma čustvene podpore in sprejemanja vloge očeta (Abidin, 1995). Iz ocen očetov lahko sklepamo, da so partnerski odnosi pri udeležencih pozitivni, $\mathrm{z}$ medsebojno podporo in skupno skrbjo za otroka. Vse to lahko interpretiramo v skladu s teorijo o pozitivni prilagoditvi staršev v družinah z dejavniki tveganja za porušeno ravnovesje (dvojni ABC$\mathrm{X}$ model; McCubbin in Patterson, 1983). Odzivanje na stresne situacije je proces, ki lahko družino privede do prilagoditve in postopne spiralne rasti ali spirale navzdol, disfunkcije in krize. Naši rezultati podpirajo tudi zaključke avtorjev (Reddon, 1989, citirano v: Skinner, Steinhauer in Santa-Barbara, 1995; Summers idr., 1988; Trute, 1990), da obstajajo družine s članom s posebnimi potrebami, ki se s pomočjo različnih podpornih storitev ali brez njih zelo dobro prilagodijo. V teh družinah poskušajo najti za svojega otroka najboljše storitve, ki so na voljo in sprejemajo posebne potrebe svojega otroka. Nižje stopnje stresa in boljša prilagoditev na življenje $\mathrm{z}$ otrokom s posebnimi potrebami sta povezana z občutki notranjega nadzora nad dogajanjem. Starši, ki se počutijo učinkovite $\mathrm{v}$ lastni starševski vlogi in doživljajo občutek nadzora nad otrokovim vedenjem, doživljajo nižje ravni stresa (Jones in Passey, 2004). Starši iz našega vzorca so ocenili statistično pomembno nižji splošni življenjski stres v primerjavi z normativnim vzorcem (stresni dogodki v zadnjem obdobju). Tudi ta okoliščina bi lahko prispevala k nižjim ocenam starševskega stresa na vseh ocenjevanih podlestvicah.

Očetje otrok s HIE poročajo o višji stopnji kakovosti življenja kot mame na vseh področjih (razen na področju zaskrbljenosti). Razlika je statistično pomembna le na področju družinskih odnosov, vendar pa je velikost učinka (Cohenov $d$ ) srednja do velika tudi na področjih telesnega delovanja, čustvenega delovanja, kognitivnega delovanja in skupne kakovosti življenja staršev. Podoben pojav avtorji opisujejo v vzorcu staršev otrok, ki doživljajo kronično bolečino (Jastrowski Mano, Anderson Khan, Ladwig in Weisman, 2011). Avtorji ponujajo razlago, da morda oba starša sicer doživljata podobne težave, povezane $\mathrm{z}$ otrokovim zdravjem, vendar jih na konkretnem vprašalniku različno izražata.

Mame in očetje otrok s HIE v povprečju doživljajo glede na normativni vzorec povprečno stopnjo starševskega stresa $(P$ =25-75). Velikost učinka razkriva, da je doživljanje starševskega stresa pri mamah izrazito nižje kot pri normativnem vzorcu na področju zaznanih starševskih kompetenc. Očetje $\mathrm{v}$ primerjavi z normativnim vzorcem doživljajo izrazito nižji stres ob interakciji $\mathrm{z}$ otrokom in občutkih o sebi ob tem, manj stresa jim predstavlja zaznavanje lastnih kompetenc pri starševstvu, manj so obremenjeni s telesnimi oziroma zdravstvenimi težavami, ki so lahko posledica starševstva, v manjši meri občutijo, da jih starševstvo ovira pri ohranjanju lastne identitete ter ne občutijo pomanjkanja čustvene in aktivne podpore pri partnerki pri vzgoji otroka. V primerjavi z mamami očetje ocenjujejo nižji starševski stres na vseh podlestvicah. Glede na statistično pomembnost in velikosti učinkov velja izpostaviti, da očetje doživljajo manj stresa na področju sprejemljivosti otroka, kar pomeni, da otrok po svojih fizičnih, intelektualnih in čustvenih značilnostih ne odstopa $\mathrm{v}$ tolikšni meri od očetovih kot od maminih pričakovanj. Mame v primerjavi z očeti v interakciji $z$ otrokom v večji meri doživljajo negativne občutke o sebi ali se počutijo zavrnjene s strani otroka. Mame so tudi bolj kot očetje obremenjene z otrokovo hiperaktivnostjo (prekomerna aktivnost, nemir, odkrenljivost, znižana pozornost, neposlušnost, nezmožnost dokončanja začete aktivnosti, težave $\mathrm{z}$ osredotočanjem na domačo nalogo). Med značilnostmi starša je pri mamah višje zaznan stres na področju depresivnosti. Mame v večji meri doživljajo pomanjkanje fizične in psihične energije za starševsko vlogo. Povišane vrednosti depresivnosti pri mamah lahko pomenijo, da s težavo zberejo fizično in psihično moč za izpolnjevanje starševskih obveznosti (Dumas, Gibson in Albin, 1989), kar se lahko kaže v umiku in splošni nezmožnosti za asertivno in avtoritativno ravnanje z otrokovimi pogostimi načini vedenja (Perez, 1989; Webster-Stratton, 1990a, 1990b; Webster-Stratton in Hammond, 1988; vse citirano v: Abidin, 1995). Razlike med ocenami mam in očetov nakazujejo na možno distanciranost med staršema in pomanjkanje vzajemne podpore v skupnem starševstvu (Abidin, 1995), kar pa je nasprotno prej omenjenemu nizkemu stresu očetov, povezanem s partnerstvom. Očetje običajno poročajo o višjem stresu, povezanem $\mathrm{z}$ otrokovim vedenjem, ne pa z lastnimi značilnostmi, njihov stres $\mathrm{v}$ večji meri blažijo dejavniki znotraj družine. Mame več pridobijo s podporo iz okolja, zato se pri njih na drugi strani tudi odsotnost te podpore bolj odslikava v višjem stresu (Abidin, 1995). Omenjene razlike v zaznani kakovosti življenja ter starševskega stresa lahko pojasnjujemo tudi s tem, da so mame in očetje na različne načine zaznamovani s starševstvom otroku s težavami ter imajo različno zaznavo vpliva otroka na njihovo življenje. To je skladno s hipotezo socialnih vlog, kjer mame prevzemajo večje breme pri skrbi za otroka in gospodinjstvo (DeaterDeckard in Scarr, 1996). Čeprav v našem primeru trend v smeri nizkih ocen starševskega stresa ni tako izrazit, ne smemo pozabiti tudi možne razlage za neobičajno nizke 
dosežke stresa pri družini s kronično bolnim otrokom, ki kažejo na možnost zanikanja, pa tudi zanemarjanja ali prepuščanja skrbi za otroka zdravstvenemu osebju (Abidin, 1995).

Pri pojasnjevanju naših rezultatov je pomembno upoštevati, da ima približno polovica otrok v našem vzorcu povprečen ali nadpovprečen izid v splošnem intelektualnem funkcioniranju. Tisti s slabšim izidom imajo v več primerih prilagoditve (na primer usmeritev $\mathrm{v}$ prilagojen program vzgoje in izobraževanja, dodatno strokovno pomoč v šoli in specialistične zdravstvene obravnave), ob katerih doživljajo manj ovir, kot bi jih sicer. Boljša razpoložljivost virov in čustvena opora iz okolja sta povezana $\mathrm{z}$ boljšim splošnim družinskim funkcioniranjem (Grossman, 1972, citirano v: Summers idr., 1988). Za natančnejši vpogled v doživljanje staršev smo v nadaljevanju med seboj primerjali družine otrok z različnimi razvojnimi izidi.

\section{Kakovost življenja družine glede na razvojni izid otroka v obdobju všolanja}

Primerjava družin glede na razvojni izid otroka nakazuje, da življenje $\mathrm{z}$ otrokom s posebnimi potrebami vendarle predstavlja izziv za družino. Skladno s pričakovanji na podlagi predhodnih raziskav (Hastings, 2002; Scorgie idr., 1998, citirano v: Jones in Passey, 2004; Nimbalkar idr., 2014; Werner in Shulman, 2013) starši otrok s podpovprečnim IQ v primerjavi s starši otrok z višjimi dosežki poročajo o več težavah v komunikaciji z ljudmi, ki ne razumejo družinskih okoliščin ter pri pogovorih z zdravstvenim osebjem. Bolj so zaskrbljeni v zvezi z zdravljenjem otroka, glede odzivov drugih na zdravstveno stanje otroka, glede vpliva bolezni na ostale člane družine ter glede otrokove prihodnosti. V teh družinah porabijo več časa in energije za dnevne aktivnosti, primanjkuje jim časa in energije za domača hišna opravila (slika 1). Podobno ugotavljajo raziskave kakovosti življenja pri starših otrok z anemijo srpastih celic (Panepinto idr., 2009), kjer so starši otrok s hudo ali blago obliko bolezni poročali o večji zaskrbljenosti ter težavah v komunikaciji v primerjavi s starši zdravih otrok. Na drugih področjih vprašalnik ni razločeval med starši bolnih in zdravih otrok. Tako kot $\mathrm{v}$ našem vzorcu so bile tudi $\mathrm{v}$ omenjeni raziskavi povprečne ocene kakovosti življenja visoke. Uporabljeni vprašalnik morda ni dovolj občutljiv za razlikovanje med starši v naših skupinah. V skupini staršev otrok z najslabšim izidom so ocene kakovosti življenja staršev najnižje na področjih socialnega delovanja, zaskrbljenosti in dnevnih aktivnosti, enako se je izkazalo v raziskavi kakovosti življenja staršev otrok s kompleksnimi zdravstvenimi težavami in je skladno tudi z raziskavami kakovosti življenja, ki so uporabljale druge merske instrumente (Johaningsmeir idr., 2015).

Starševski stres je pri skupini staršev otrok z najslabšim razvojnim izidom višji na področju prilagodljivosti, zahtevnosti in sprejemljivosti otroka ter na področju kompetenc, izolacije in omejitve vloge starša (slika 2), kar smo pričakovali glede na to, da otroci z razvojnimi težavami pogosteje izkazujejo problematično vedenje, ki vztraja skozi čas (Totsika in Hastings, 2009, citirano v: Woodman, 2014). To je skladno tudi z ugotovitvami, da je kakovost življenja slabša in starševski stres višji v družinah $\mathrm{z}$ otroki s slabšimi izidi po HIE, zdravljeni s TH (Chouchan, Sinh in Kumar, 2016) ter z izsledki S. Shankaran in sodelavcev (2005), ki ugotavljajo večji negativni skupni učinek, finančni učinek, večje breme za skrbnika in družino ter večjo motnjo načrtovanja aktivnosti v družini pri tistih, ki so imeli zmerno ali hudo oškodovanost po HIE. Avtorji zaključujejo, da so zdravstveni izidi po bolezni otroka lahko pod vplivom stresnega doživljanja družine, kar pomeni, da lahko s podporo družini potencialno izboljšamo tudi otrokove dolgoročne izide. Opisane razlike so statistično pomembne predvsem med skupino otrok $\mathrm{z}$ najnižjimi (skupina 1) in s povprečnimi izidi (skupina 2). V družinah otrok z nadpovprečnimi izidi (3) so rezultati sicer bolj podobni skupini 2, vendar niso statistično pomembno drugačni kot $\mathrm{v}$ skupini 1. To lahko najverjetneje pripišemo temu, da je numerus otrok v skupini 3 zelo majhen, zato se opažena razlika ne potrdi kot pomembna. Pri pregledu slike 1 in 2 lahko vendarle opazujemo zanimiv pojav, da so najboljšo kakovost življenja in najnižje ravni stresa večinoma ocenjevali starši otrok s povprečnim IQ. Smiselno bi bilo v nadaljevanju raziskovati, kateri so dejavniki, ki znižujejo ocene staršev otrok v skupini $3 \mathrm{v}$ primerjavi s skupino 2.

Starši so v razgovorih med sodelovanjem v raziskavi izpostavljali negotovosti in strah, ki so ju doživljali predvsem v zgodnejšem obdobju - po rojstvu otroka ob diagnozi in ob akutnem zdravljenju otroka. To je skladno z izsledki raziskav doživljanja stresa ob rojstvu otroka z rizičnimi dejavniki (Heringhaus idr., 2013). Ker lahko stres v družini vpliva na otrokov razvoj, je potrebno že na začetku usmerjati pozornost na doživljanje stresa in ga sistematično ocenjevati, kasneje pa spremljati otrokov razvoj in delovanje družine. Starši izpostavljajo nepovezanost storitev, ki jih je deležen njihov otrok $\mathrm{s}$ posebnimi potrebami, nesistematičnost in neusklajenost posameznih strokovnjakov ter dolge čakalne dobe. Posamezne družine pomoč iščejo v različnih storitvah, ki niso nujno znanstveno utemeljene, poleg tega pa predstavljajo finančno breme za družino.

\section{Omejitve raziskave}

Raziskovalni vzorec je majhen kljub nizkemu osipu udeležencev, saj je število otrok po HIE, zdravljenih s TH na KO OKIT, ob majhnosti slovenske populacije nizko. Tudi iz tega razloga bi bilo smiselno to področje raziskovati s kvalitativnimi metodami. Čeprav so uporabljeni pripomočki standardizirani in pogosto uporabljani, gre za samoocenjevalne vprašalnike, ki so podvrženi subjektivni oceni. Za primerjavo so uporabljeni normativni podatki, pridobljeni na vzorcih udeležencev, ki se lahko razlikujejo od našega vzorca. S podrobnejšimi individualnimi intervjuji od začetka zdravljenja otroka naprej bi lahko bolj učinkovito odkrivali specifične potrebe posameznih družin od vključitve otroka v zdravljenje naprej. Otroci, vključeni v raziskavo, imajo morda druge pridružene somatske bolezni in motnje, ki niso povezane s samo HIE, imajo pa pomemben vpliv na delovanje družine. Poleg tega obstaja možnost, da imajo v družinah z več otroki tudi sorojenci otrok iz našega vzorca različne težave, ki pomembno sooblikujejo družinsko delovanje ter vplivajo na povišan starševski stres. Ocene 
staršev torej niso nujno povezane le $\mathrm{z}$ delovanjem otrok iz našega vzorca. Zaradi delovanja družine kot sistema pa omenjen vpliv sorojencev zelo težko nadzorujemo. Še eno omejitev predstavlja merjenje konstruktov kakovosti življenja in starševskega stresa, ki odraža trenutno stanje (navodilo pri vprašalniku PedsQL-FIM se nanaša na zadnji mesec), ki morda ni reprezentativno za določeno družino.

\section{Zaključek}

Ugotavljamo, da v povprečju kakovost življenja družin otrok s HIE, zdravljeno s TH, ni slabša in starši ne doživljajo višje ravni stresa kot v družinah z zdravimi otroki. Na podlagi tega bi lahko zaključili, da se družine s članom s posebnimi potrebami $\mathrm{V}$ povprečju dobro prilagodijo specifičnim razmeram. Če pa pogledamo le družine otrok z najslabšimi razvojnimi izidi, postane bolj očitno, da otrokovo stanje pomembno vpliva na nekatere vidike življenja celotne družine. Otrok s HIE, zdravljenih s TH, ne moremo obravnavati kot homogene skupine, saj so razvojni izidi teh otrok različni, $\mathrm{s}$ tem pa so specifične tudi značilnosti in potrebe otrok in njihovih družin. V naši raziskavi smo ugotovili, da vprašalnik PSI-III bolje kot PedsQL-FIM diskriminira med skupinami glede na razvojni izid pri otroku. Družine se v veliki meri prilagodijo izzivom, ki jih prinaša skrb za otroka s posebnimi potrebami, vendar imajo pri tem večje časovne, fizične in psihološke obremenitve, nemalokrat se soočajo z izpadom dohodka, visokimi stroški ter pomanjkanjem časa za ostale družinske člane (Johaningsmeir idr., 2015). Potrebno je še naprej raziskovati dejavnike, ki so najtesneje povezani $\mathrm{z}$ boljšim ali slabšim delovanjem družine $\mathrm{z}$ namenom razvoja in nudenja individualiziranih pristopov podpore družini (Lemmon idr., 2016).

V nadaljnjih raziskavah se je smiselno usmeriti na obdobje ob rojstvu in zgodnji intenzivni obravnavi otroka. Intervencije, ki se osredotočajo na razvijanje spretnosti in virov za blaženje in zmanjševanje stresa v družini, imajo potencialno ugoden učinek na izboljševanje odpornosti in pozitivnih dolgoročnih izidov v družinah (Singer, Ethridge in Aldana, 2007). Starše je pomembno osveščati, da je stres in vedenje, povezano $s$ povečanim stresom, mogoče uravnavati ter da so uspešne strategije prilagajanja na voljo vsem družinam (Summers idr., 1988). V prihodnosti bi bilo smiselno preverjati stanje otroka in družine ob pomembnih mejnikih, kot je prehod iz osnovne v srednjo šolo in prehod iz mladostništva v odraslost.

Stres je negativno povezan $\mathrm{s}$ formalno podporo za oba starša (Abidin, 1995), zato je nudenje psihosocialnih oblik formalne podpore družinam utemeljen. Starši imajo pomembno korist ob vključitvi v strokovne oblike pomoči, kot je individualna ali skupinska terapija (Lindo idr., 2016). Starše je potrebno učiti različnih starševskih spretnosti in strategij, ki omogočajo pridobivanje nadzora nad otrokovimi vedenjskimi težavami. Pri podpiranju razvoja samostojnosti otroka sta koristna pomoč in svetovanje drugih družin (Akre, Ramelet, Berchtold in Suris, 2015). Staršem je potrebno ponuditi podporo takoj ob postavitvi otrokove diagnoze, saj lahko s tem zmanjšujemo nihanja doživljanja starševskega stresa preko življenja ali celo preprečimo razvoj vedenjskih težav pri otroku (Jones in Passey, 2004).
Strokovni delavci v klinični praksi morajo starše, kadar je to mogoče, usmeriti $\mathrm{k}$ virom pomoči v lokalnem okolju, jih seznaniti z organizacijami na državni ravni, z nevladnimi organizacijami in društvi ter s spletnimi stranmi, ki posedujejo zbrane informacije in sezname možnih oblik pomoči in podpore (Reichman idr., 2008). Podpora zdravstvene in socialne politike ter sistemov financiranja je nujna za zagotavljanje kakovostne skrbi za to naraščajočo ranljivo populacijo (Cheak-Zamora in Thullen, 2017).

\section{Literatura}

Abidin, R. R. (1995). Parenting Stress Index: Professional manual (3rd Ed.). Odessa, FL, ZDA: Psychological Assessment Resources.

Akre, C., Ramelet, A.-S., Berchtold, A. in Suris, J.-C. (2015). Educational intervention for parents of adolescents with chronic illness: A pre-post test pilot study. International Journal of Adolescent Medicine and Health, 27(3), 261-269.

Biarent, D., Bingham, R., Eich, C., López-Herce, J., Maconochie, I., Rodríguez-Núñez in Zideman, D. (2010). European resuscitation council guidelines for resuscitation 2010: Section 6: Paediatric life support. Resuscitation, 81(10), 1364-1388.

Bonifacio, S. L., deVries, L. S. in Groenendaal, F. (2015). Impact of hypothermia on predictors of poor outcome: How do we decide to redirect care? Seminars in Fetal \& Neonatal Medicine, 20(2), 122-127.

Bregant, T., Neubauer, D. in Derganc, M. (2012). Kakovost življenja mladostnikov, ki so v obdobju novorojenčka utrpeli hipoksično ishemično encefalopatijo [Quality of life in adolescents followed after neonatal hypoxicishaemic encephalopathy]. Zdravstveni vestnik, 81, 383-392.

Centers for Disease Control and Prevention (2016). Healthrelated quality of life (HRQOL). Pridobljeno s http:// www.cdc.gov/hrqol/index.htm

Cheak-Zamora, N. C. in Thullen, M. (2017). Disparities in quality and access to care for children with developmental disabilities and multiple health conditions. Maternal and Child Health Journal, 21(1), 36-44.

Chouchan, S. C., Sinh, P. in Kumar, S. (2016). Assessment of stress and anxiety in parents of children with intellectual disability. Indian Journal of Health and Wellbeing, 7(5), 500-504.

Cohen, M. S. (1999). Families coping with childhood chronic illness: A research review. Families, Systems, and Health, $17(2), 149-164$

Deater-Deckard, K. in Scarr, S. (1996). Parenting stress among dual-earner mothers and fathers: Are there gender differences? Journal of Family Psychology, 10, 45-59.

Derganc, M., Škofljanec, A., Paro-Panjan, D., Kodrič, J., Osredkar, D. in Neubauer, D. (2015). Terapevtska hipotermija v Sloveniji. V Neubauer, D., Osredkar, D. (ur.). PTON III: Podiplomski tečaj otroške in razvojne nevrologije 2015/2016: izbor predavanj (1. del od 3) [ PTONIII: Postgraduate Course in Child and Development Neurology 2015/2016: Lecture selection (Part 1 of 3)] (str. 361-378). Ljubljana, Slovenija: Medicinska fakulteta, Center za razvojno nevroznanost. 
Dumas, J. E., Gibson, J. A. in Albin, J. B. (1989). Behavioral correlates of maternal depressive symptomatology in conduct-disorder children: II. Systemic effects involving fathers and siblings. Journal of Consulting and Clinical Psychology, 58(6), 877-881.

Hastings, R. (2002). Parental stress and behaviour problems of children with developmental disabilities. Journal of Intellectual and Developmental Disability, 27, 149-160.

Heringhaus, A., Blom, M. D. in Wigert, H. (2013). Becoming a parent to a child with birth asphyxia-From a traumatic delivery to living with the experience at home. International Journal of Qualitative Studies on Health and Well-Being, 8, 1-13.

Hyde, J. S. (2005). The gender similarities hypothesis. American Psychologist, 60, 581-592.

Inder, T. E. in Volpe, J. J. (2000). Mechanisms of perinatal brain injury. Seminars in Neonatalogy, 5(1), 3-16.

Jacobs, S. E., Berg, M., Hunt R., Tarnow-Mordi, W. O., Inder, T. E. in Davis, P. G. (2013). Cooling for newborns with hypoxic ischaemic encephalopathy. Cochrane Database of Systematic Reviews, 2013(1), Art. No. CD003311.

Jastrowski Mano, K. E., Anderson Khan, K., Ladwig, R. J. in Weisman S. J. (2011). The impact of pediatric chronic pain on parents' health-related quality of life and family functioning: Reliability and validity of the PedsQL 4.0 Family Impact Module. Journal of Pediatric Psychology, 36(5), 517-527.

Johaningsmeir, S. A., Colby, H., Krauthoefer, M., Simpson, P., Conceição, S. C. in Gordon, J. B. (2015). Impact of caring for children with medical complexity and high resource use on family quality of life. Journal of Pediatric Rehabilitation Medicine, 8(2), 75-82.

Jones, J. in Passey, J. (2004). Family adaptation, coping and resources: Parents of children with developmental disabilities and behaviour problems. Journal on Developmental Disabilities, 11(1), 31-46.

Kazak, A. in Marvin, R. (1984). Differences, difficulties and adaptation: Stress and social networks in three samples. Journal of Abnormal Child Psychology, 15, 137-146.

Keller, D. in Sterling Honig, A. (2004). Maternal and paternal stress in families with school-aged children with disabilities. American Journal of Orthopsychiatry, 74(3), $337-348$.

Kreft, I. (2011). Soočanje družine s kronično ledvično boleznijo otroka (neobjavljena doktorska disertacija) [Family coping with child's chronic kidney disease (unpublished doctoral dissertation)]. Filozofska fakulteta Univerze v Ljubljani, Slovenija.

Lemmon, M. E., Donohue, P. K., Parkinson, C., Northington, F. J. in Boss, R. D. (2016). Parent experience of neonatal encephalopathy: The need for family-centered outcomes. Journal of Child Neurology, 32(3), 286-292.

Lindo, E. J., Kliemann, K. R., Combes, B. H. in Frank, J. (2016). Managing stress levels of parents of children with developmental disabilities: A meta-analytic review of interventions. Family Relations, 65, 207-224.

Marlow, N., Rose, A. S., Rands, C. E. in Draper, E. S. (2005). Neuropsychological and educational problems at school age associated with neonatal encephalopathy. Archives of Disease in Childhood: Fetal and Neonatal Edition, 90(5), 380-387.
Medrano, G. R., Berlin, K. S. in Davies, W. H. (2013). Utility of the PedsQL ${ }^{\text {TM }}$ Family Impact Module: Assessing the psychometric properties in a community sample. Quality of Life Research, 22, 2899-2907.

McCubbin, H. I. in McCubbin, M. A. (1988). Typologies of resilient families: Emerging roles of social class and ethnicity. Family Relations, 37(3), 247-254.

McCubbin, H. I. in Patterson, J. M. (1983). The family stress process: The double ABCX model of family adjustment and adaptation. Marriage and Family Review, 6, 7-37.

Minnes, P. (1988). Family resources and stress associated with a developmentally handicapped child. American Journal of Mental Retardation, 93, 184-192.

Nimbalkar, S., Raithatha, S., Shah, R. in Panchal, D. A. (2014). A qualitative study of psychosocial problems among parents of children with cerebral palsy attending two tertiary care hospitals in Western India. ISRN Family Medicine, 2014(769619).

Panepinto, J. A., Hoffman, R. G. in Pajewski, N. M. (2009). A psychometric evaluation of the PedsQL ${ }^{\text {TM }}$ Family Impact Module in parents of children with sickle cell disease. Health and Quality of Life Outcomes, 7(1), 32-42.

Radić, S., Grosek, Š., Osredkar, D. in Derganc, M. (2007). Zdravljenje novorojenke $\mathrm{s}$ hipoksično-ishemično encefalopatijo z uporabo sistemske hipotermije - prikaz primera [Tretment of a newborn with a hypoxic ischaemic encephalopathy using the systemic hypothermia]. Slovenska pediatrija, 14, 192-197.

Reichman, N. E., Corman, H. in Noonan, K. (2008). Impact of child disability on the family. Maternal and Child Health Journal, 12(6), 679-683.

Shankaran, S. (2012). Therapeutic hypothermia for neonatal encephalopathy. Current Treatment Options in Neurology, 14(6), 608-619.

Shankaran, S., Laptook, A. R., Ehrenkranz, R. E., Tyson, J. E., McDonald, S. A., Donovan, E. F., ... Jobe, A. H. (2005). Whole-body hypothermia for neonates with hypoxicischemic encephalopathy. The New England Journal of Medicine, 353, 1574-1584.

Singer, G. H., Ethridge, B. L. in Aldana, S. L. (2007). Primary and secondary effects of parenting and stress management interventions for parents of children with developmental disabilities: A meta-analysis. Mental Retardation and Developmental Disabilities, 13, 357-369.

Skinner, H., Steinhauer, P. D. in Santa-Barbara, J. (1995). Family Assessment Measure III (FAM III). New York: Multi-Health Systems Inc.

Summers, J. A., Behr, S. K. in Turnbull, A. P. (1988). Positive adaptation and coping strengths of families who have children with disabilities. V G. H. S. Singer in L. K. Irvin (ur.), Support for caregiving families: Enabling positive adaptation to disability (str. 27-40). Baltimore, MD, ZDA: Brookes.

Trute,B.(1990).Childandparentpredictorsoffamilyadjustment in households containing young developmentally disabled children. Family Relations, 39(3), 292-297.

Varni, J. W. (2017). The Peds $Q L^{T M}$. Pridobljeno s http://www. pedsql.org/

Varni, J. W., Seid, M. in Rode, C. A. (1999) The PedsQL: Measurement model for the pediatric quality of life inventory. Medical Care, 37(2), 126-139. 
Varni, J. W., Sherman, S. A., Burwinkle, T. M., Dickinson, P. E. in Dixon, P. (2004). The PedsQL ${ }^{\mathrm{TM}}$ Family Impact Module: Preliminary reliability and validity. Health and Quality of Life Outcomes, 2, 55.

Volpe, J. J. (1995). Neurology of the newborn (3rd ed.). Philadelphia, PA; ZDA: WB Saunders.

Wechsler, D., Boben, D., Bucik, V. in Kovačič, D. (2001). WISC-III': Wechslerjeva lestvica inteligentnosti za otroke: Priročnik [WISC-IIIII Wechsler Intelligence Scale for Children: Manual]. Ljubljana, Slovenija: Center za psihodiagnostična sredstva.

Wechsler, D., Gosar, D., Boben, D. in Kovačič, D. (2013). WPPSI-III ${ }^{S I}$ : Wechslerjeva lestvica inteligentnosti za predšolske otroke: Priročnik [WPPSI-IIIII: Wechsler Preschool and Primary Scale of Intelligence: Manual]. Ljubljana, Slovenija: Center za psihodiagnostična sredstva.

Werner, S. in Shulman, C. (2013). Subjective well-being among family caregivers of individuals with developmental disabilities: The role of affiliate stigma and psychosocial moderating variables. Research in Developmental Disabilities, 34, 4103-4114.

Woodman, A. C. (2014). Trajectories of stress among parents of children with disabilities: A dyadic analysis. Family Relations, 63(1), 39-54.

Yager, J. Y., Armstrong, E. A., Jaharus, C., Saucier, D. M. in Wirrell, E. C. (2004). Preventing hyperthermia decreases brain damage following neonatal hypoxic-ischemic seizures. Brain Research, 1011(1), 48-57. 